\title{
Dosificación de un mortero refractario cemento-talco-chamota sometido a choque térmico
}

\author{
Dosification of a cement-talc-chamotte \\ refractory mortar subjected to thermal shock
}

\author{
P. KITTL, G. DIAZ y H. ALARCÓN \\ Departamento de Ingeniería de Materiales, IDIEM, Facultad de Ciencias Fisicas y Matemáticas \\ Universidad de Chile, Casilla 1420, Santiago, Chile
}

Fecha de recepción: 16-XII-91

\section{RESUMEN}

Se dosificó una mezcla refractaria cemento-talco-chamota sometiéndola a un choque térmico. Con este objeto se fabricaron probetas compactadas a $350 \mathrm{~kg} / \mathrm{cm}^{2}$ mediante compresión y probetas compactadas manualmente. Se aplicó a todas ellas una temperatura inicial de trabajo a $1.000^{\circ} \mathrm{C}$, luego se las dejó enfriar hasta que alcanzaran la temperatura de sala del laboratorio. El choque térmico se originó calentando las probetas en un horno hasta una temperatura $T_{i}$ y luego se las enfrió súbitamente sumergiéndolas en agua a $20^{\circ} \mathrm{C}$; la temperatura $T_{i}$ varió entre $170^{\circ} \mathrm{C}$ y $970^{\circ} \mathrm{C}$ con incrementos de $100^{\circ} \mathrm{C}$. La dosificación óptima, 90 \% cemento-talco y $10 \%$ chamota, se obtuvo estudiando la tensión media de fractura a la compresión de cinco mezclas de cemento-talco-chamota en función del choque térmico. Se estudió además la fatiga térmica de la dosificación óptima determinando la pérdida media de resistencia a la compresión, la que alcanzó al 52 $\%$ después de 7 ciclos con $\Delta T=500^{\circ} \mathrm{C}$.

\author{
SUMMARY
}

A cement-talc-chamotte refractory mixture was dosified by subjecting the same to thermal shock. To this end, specimens compacted to $350 \mathrm{Kg} / \mathrm{cm}^{2}$ through compression as well as specimens compacted manually were prepared. All the specimens were submitted to an initial working temperature of $1.000^{\circ} \mathrm{C}$ and then left to cool down to room temperature. The thermal shock was originated by heating the specimens in an oven till reaching a certain temperature $T_{i}$ and then quenching the same through immersion in water at $20^{\circ} \mathrm{C}$; temperature $T_{\text {; }}$ was varied between $170^{\circ} \mathrm{C}$ and $970^{\circ} \mathrm{C}$ by means of $100^{\circ} \mathrm{C}$ increments. The optimum dosification amounting to $90 \%$ cement-talc and $10 \%$ chamotte was obtained by studying mean stress at compression fracture of five cement-talc-chamote mixtures as a function of thermal shock. In addition, thermal fatigue exhibited by the optimum dosification was studied through the determination of mean loss in compressive strength, which amounted to $52 \%$ after 7 cycles with $\Delta T=500^{\circ} \mathrm{C}$.

\section{INTRODUCCIÓN}

Es bien conocido que pastas de cemento portland sometidas a ciclos de calentamiento con temperaturas máximas sobre $400^{\circ} \mathrm{C}$ y expuestas a una atmósfera húmeda a temperatura de sala, desarrollan tensiones internas que producen agrietamiento del material [1]. Esto es debido a la deshidratación del $\mathrm{CH}$ a temperaturas sobre $400^{\circ} \mathrm{C}$ seguida de una posterior hidratación en atmósfera húmeda. En un trabajo previo Kittl y Rodríguez [2] discutieron el comportamiento mecánico de una mezcla cemento-talco sometida a ciclos térmicos de $600^{\circ} \mathrm{C}-20^{\circ} \mathrm{C}$ (bajo humedad). En otro trabajo posterior, Kittl et al [3] estudiaron la evolución seguida por el hidróxido de calcio al deshidratarse durante ciclos térmicos aplicados a la misma mezcla. La mezcla óptima de cemento

\section{INTRODUCTION}

It is well-known that portland cement paste subjected to heating cycles with maximum temperatures above $400^{\circ} \mathrm{C}$ and exposed to a moist environment at room temperature, develops internal stresses that produce material fragmentation (1). This is due to $\mathrm{CH}$ dehydration at temperatures over $400^{\circ} \mathrm{C}$ followed by hydration in the moist environment. In a previous work, Kittl and Rodriguez (2) discussed the mechanical behaviour of a cement-talc mixture subjected to several thermal cycles of $600^{\circ} \mathrm{C}-20^{\circ} \mathrm{C}$ (under moisture). In a posterior work, moreover, Kittl et al (3) studied the evolution of calcium hydroxide disappearance during thermal cycles in the same mixture. The characteristics exhibited by a mixture of cement and $35 \%$ talc are optimum regarding 
talco fue cemento $65 \%$ y talco $35 \%$ y se determinó estudiando su resistencia mecánica en función de ciclos térmicos a temperaturas inferiores a $600^{\circ} \mathrm{C}$, obteniéndose un cemento refractario. Las chamotas resistentes al fuego son los agregados más utilizados en hormigones resistentes a elevadas temperaturas, en la mayoría de los casos se las emplea en forma similar al agregado ordinario. También se han usado chamotas livianas en hormigones refractarios de bajo peso. El objetivo del presente trabajo es, usando la mezcla cemento- $35 \%$ talco, obtener la dosificación óptima de una mezcla cemento-talco-chamota resistente a ciclos térmicos.

\section{PROCEDIMIENTO EXPERIMENTAL}

Se empleó cemento portland comercial sin aditivos cuya composición en peso y características físicas fue la siguiente: $61.4 \% \mathrm{C}$, $20.42 \%$ S, $7.16 \%$ A, $2.76 \%$ F y $1.72 \% \mathrm{M}$, superficie específica $305 \mathrm{~m}^{2} / \mathrm{kg}$; retención $13.6 \%$ en malla de $45 \mu \mathrm{m}$. La composición en peso y las características físicas del talco fueron las siguientes: $4.56 \%$ C, $52.96 \%$ S, $2.48 \%$ A, $6.27 \%$ F y $25.97 \%$ M; superficie específica $780 \mathrm{~m}^{2} / \mathrm{kg}$; retención $1.4 \%$ en malla de $45 \mu \mathrm{m}$. Se empleó una chamota sílico-aluminosa finamente molida.

Se prepararon cinco dosificaciones de cementotalco-chamota en las que el cemento refractario cemento-talco tenía una composición $65 \%$ cemento y $35 \%$ talco, al cual se agregó chamota entre $0 \%$ y $40 \%$, todos los porcentajes en peso. Se tamizó el cemento refractario a fin de obtener una mezcla homogénea. Se confeccionaron dos grupos de probetas con las cinco dosificaciones, un grupo se compactó por compresión a $350 \mathrm{~kg} / \mathrm{cm}^{2}$ en una máquina Amsler, mientras que el otro grupo se compactó manualmente con un pisón de hierro con punta semiesférica de $0.006 \mathrm{~m}$ de diámetro. Para el primer grupo se confeccionaron 340 probetas con un $5 \%$ en peso de agua y compactadas en un molde de acero cilíndrico, 50 de ellas fueron de pasta pura de cemento. Con este procedimiento se obtuvieron cilindros de $0.022 \mathrm{~m}$ de diámetro y $0.044 \mathrm{~m}$ de altura. Las muestras se almacenaron en cámara húmeda a $20^{\circ} \mathrm{C}$ por $24 \mathrm{~h}$. A fin de que la hidratación progresara tanto como fuera posible las muestras se sumergieron en agua hasta la saturación y se almacenaron nuevamente en la cámara húmeda hasta completar 15 días. Para el segundo grupo se confeccionaron 150 probetas con un $40 \%$ en peso de agua y apisonadas en un molde plástico cilíndrico que tenía un corte longitudinal para facilitar el desmolde, su estanquidad se aseguró sellando el corte con cinta adhesiva. El molde se llenó por capas compactándolas sucesivamente con el pisón. Se obtuvieron así cilindros de $0.021 \mathrm{~m}$ de diámetro y strength against thermal cycles and temperatures bellow $600^{\circ} \mathrm{C}$, i.e. a refractory cement. Fireresistant chamottes are the aggregates most frequentrly employed in high-temperature-resistant concretes; in the majority of instances they are being used similarly to ordinary aggregates. Lightweight chamottes have also been used to make lightweight refractory concrete (4). The aim of the present work is employing the mixture made of cement and $35 \%$ talc in order to obtain the optimum dosification of a cement-talcchamotte mixture resisting to thermal cycles.

\section{EXPERIMENTAL PROCEDURE}

Comercial portland cement devoid of additives and whose composition by weight and physical characteristics were as follows: $61.4 \% C$, $20.42 \% S, 7.16 \% A, 2.76 \% F$ and $1.72 \% M$; specific surface $305 \mathrm{~m}^{2} / \mathrm{kg}$; retention on a moist $45 \mu \mathrm{m}$ sieve: $13.6 \%$; was used. The talc employed exhibited the following composition by weight and physical characteristics: $4.56 \% \mathrm{C}$, $52.96 \%$ S, $2.48 \% A, 6.27 \% F$ and $25.97 \%$ M; specific surface $780 \mathrm{~m}^{2} / \mathrm{kg}$; retention on a moist $45 \mu \mathrm{m}$ sieve: $1,4 \%$. Finely ground silicoaluminous chamotte was used.

Five dosifications of cement-talc-chamotte were prepared so that the refractory cement composition included, by weight, $65 \%$ cement and $35 \%$ talc, to which the chamotte was added in an amount ranging from $0 \%$ to $40 \%$. The refractory cement was sieving in order to obtain homogenity mixture. Two groups of test specimens were readyed with the five dosifications, namely: one group was compacted to $350 \mathrm{~kg} / \mathrm{cm}^{2}$ on an Amsler machine, while the other group was subjected to manual compactation using an iron rammer fitted with a hemispherical end $0.006 \mathrm{~m}$ in diameter. The first group comprised 340 specimens containing $5 \%$ by weight of water, which were compacted in a cylindrical steel mould. 50of these specimens were made of neat-cement paste. Cylinders $0.022 \mathrm{~m}$ in diameter and $0.044 \mathrm{~m}$ high were produced in this fashion. The specimens were kept in a mosit room at $20^{\circ} \mathrm{C}$ for $24 \mathrm{~h}$. In order that hydration may proceed as much as possible the specimens were immersed in water till saturation and thereafter they were again placed in the moist room until completing 15 days. The second group of test specimens comprised 150 units containing a $40 \%$ by weight of water, which were rammed within a plastic mould longitudinally split to ease demoulding and whose tightness was insured by sealing this split portion with adhesive tape. The mould was gradually filled with succesive layers of which each one was subjected to ramming. Cylinders $0.021 \mathrm{~m}$ in diameter and 
$0.042 \mathrm{~m}$ de altura. Las muestras se almacenaron en cámara húmeda a $20^{\circ} \mathrm{C}$ por $72 \mathrm{~h}$, se desmoldaron y se mantuvieron en la cámara húmeda hasta completar 15 días. El proceso de hidratación, para los dos grupos de probetas, se detuvo colocando las muestras en un horno a $110^{\circ} \mathrm{C}$ por $24 \mathrm{~h}$ obteniéndolas secas, las que se almacenaron a continuación en un desecador hasta que fueran ensayadas.

Todas las probetas se sometieron a un tratamiento térmico previo: se las colocó en un horno a $150^{\circ} \mathrm{C}$ durante $24 \mathrm{~h}$ con el fin de eliminar el agua libre que aún tuvieran. Luego se elevó lentamente la temperatura hasta alcanzar $550^{\circ} \mathrm{C}$, temperatura a la que permanecieron otras $24 \mathrm{~h}$ con el fin de liberar el agua del hidróxido de calcio. A continuación se volvió a alzar la temperatura hasta $1.000^{\circ} \mathrm{C}$, temperatura que se mantuvo durante $3 \mathrm{~h}$. Se apagó el horno y se las dejó enfriar lentamente durante dos días en el interior del horno. Simulando con lo anterior una temperatura de trabajo para todas las dosificaciones y para los dos procesos de fabricación.

Con todas las probetas a la temperatura de sala, $T_{0}$, se inició el choque térmico. Se introdujeron 5 probetas, de cada dosificación y de cada proceso de fabricación, en un horno hasta alcanzar una temperatura $T_{i}$ que se mantuvo durante $1 \mathrm{~h}$ a fin de homogeneizarla en el seno de las probetas. Se las retiró rápidamente del horno y se sumergieron en agua a $20^{\circ} \mathrm{C}$. La temperatura $T_{i}$ varió desde una temperatura mínima de $170^{\circ} \mathrm{C}$ con incremento de $100^{\circ} \mathrm{C}$ en $100^{\circ} \mathrm{C}$ hasta una temperatura máxima de $970^{\circ} \mathrm{C}$ o hasta una temperatura $T_{k}$, menor o igual a $970^{\circ} \mathrm{C}$, tal que las probetas no resistan el choque térmico, es decir, que se rompan por efecto de éste. $T_{k}=T_{i}+100^{\circ} \mathrm{C}$ donde $i=1,2, \ldots, k-1$. Entonces el choque térmico queda definido por $\Delta \mathrm{T}_{\mathrm{i}}=\mathrm{T}_{\mathrm{i}}-20^{\circ} \mathrm{C}, \mathrm{i}=1,2, \ldots, \mathrm{k}, \Delta \mathrm{T}_{0}=0$. Luego se las extrajo del agua y se las dejó enfriar hasta $T_{0}$ sobre una placa refractaria. En la Tabla 1 se resumen de acuerdo al proceso de fabricación de las probetas, su dosificación, el número de ellas y la máxima diferencia de temperatura $\Delta T_{k}$ en el choque térmico.

Con 40 probetas de la dosificación óptima, de mejor respuesta al choque térmico, se realizó un test de fatiga térmica. La experiencia es análoga a la del choque térmico, aquí se fijo $\Delta T=500^{\circ} \mathrm{C}$. Las probetas se sometieron a choques térmicos sucesivos hasta un máximo de siete ciclos o hasta que fallaran, es decir, se rompan por efecto del choque térmico, antes de completar tales ciclos.

Se efectuó un ensayo de compresión simple en una máquina Amsler a todas aquellas probețas que resultaron ilesas el choque térmico, con lo
$0.042 m$ high were obtained in this way. The specimens were kept in a moist room at $20^{\circ} \mathrm{C}$ for $72 \mathrm{~h}$, then they were demoulded and kept in the moist room until completing 15 days. The hydration process of the two groups of specimens was ended by placing these units in an oven at $110^{\circ} \mathrm{C}$ for $24 \mathrm{~h}$ in order to get dry specimens, and thereafter the same were stored in a dessicator till testing time.

All the specimens were subjected to a prior thermal treatment, as follows: They were placed in an oven at $150^{\circ} \mathrm{C}$ for $24 \mathrm{~h}$ to the end of eliminating free water still present. Then temperature was gradually raised till reaching $550^{\circ} \mathrm{C}$, and specimens were kept at that temperature during further $24 \mathrm{~h}$ in order to release water contained in calcium hydroxide. Then temperature was again raised to $1.000^{\circ} \mathrm{C}$ and maintained thus for $3 h$. The oven was put out and the specimens were left therein so as to be gradually cooling during a couple of days, thus simulating a working temperature for all the dosifications and for the two manufacturing processes.

The thermal shock was initiated with all the specimens at room temperature $T_{0}$. Five specimens of each manufacturing process were placed in an oven till reaching a certain temperature $T_{i}$ that was maintained during $1 \mathrm{~h}$ in order to homogenize it within the specimens. Thereafter these were quickly withdrawn from the oven and submerged in water at $20^{\circ} \mathrm{C}$. Temperature $T_{i}$ was raised by increments of $100^{\circ} \mathrm{C}$ from a minimum temperature of $170^{\circ} \mathrm{C}$ till maximum temperature of $970^{\circ} \mathrm{C}$ or till a temperature $T_{k}$, minor or equal to $970^{\circ} \mathrm{C}$, such that the specimens did not withstand thermal shock and fractured owing to the same, at $T_{k}=T_{i}$ $+100^{\circ} \mathrm{C}$ where $i=1,2, \ldots, k-1$. Thus thermal shock is defined by $\Delta T_{i}=T_{i}-20^{\circ} \mathrm{C}$, $i=1,2, \ldots, k, \Delta T_{o}=0$. Then the specimens were removed from water and were left to cool to room temperature $T_{0}$ on a refractory plate. Table 1 is summarising the manufacturing process of the specimens, their dosification, their number, and the maximum temperature difference $\Delta T_{k}$ of thermal shock.

40 specimens of the optimum dosification and exhibiting the best response to thermal shock were subjected to a thermal-fatigue test. The experiment is similar to that of thermal shock, and $\Delta T=500^{\circ} \mathrm{C}$ was chosen here. The specimens were submitted to succesive thermal shocks until a maximum of seven cycles or until failure through fracture caused by thermal shock before completing such cycles.

A simple compression test using an Amsler machine was carried out on all those specimens that withstood the thermal shock, and thus mean 
TABLA 1 TABLE 1

Proceso de fabricación, dosificación del cemento-talco-chamota, número de probetas y máxima diferencia de temperaturas $\Delta T_{k}$ en el choque térmico

(Manufacturing Process, Cement-Talc-Chamotte Dosification, Specimens Number, and Maximum Temperature $\Delta T_{k}$ of Thermal Shock)

\begin{tabular}{|c|c|c|c|c|c|}
\hline \multirow{2}{*}{$\begin{array}{c}\text { Proceso de } \\
\text { fabricación } \\
\text { (Manufacturing } \\
\text { Process) }\end{array}$} & \multicolumn{3}{|c|}{$\begin{array}{l}\text { Dosificación, \% en peso } \\
\text { (Dosification \% by Weight) }\end{array}$} & \multirow{2}{*}{$\begin{array}{l}\text { Número de } \\
\text { probetas } \\
\text { (Number of } \\
\text { Specimens) }\end{array}$} & \multirow{2}{*}{$\Delta T_{k}\left({ }^{\circ} \mathrm{C}\right)$} \\
\hline & \multicolumn{2}{|c|}{$\begin{array}{l}\text { Cemento-Talco } \\
\text { (Cement-Talc) }\end{array}$} & $\begin{array}{l}\text { Chamota } \\
\text { (Chamotte) }\end{array}$ & & \\
\hline $\begin{array}{l}\text { Compactadas a } \\
350 \mathrm{~kg} / \mathrm{cm}^{2} \\
\text { (Compactation } \\
\text { to } 350 \mathrm{~kg} / \mathrm{cm}^{2} \text { ) }\end{array}$ & $\begin{array}{l}\text { (A) } \\
\text { (B) } \\
\text { (C) } \\
\text { (D) } \\
\text { (E) }\end{array}$ & $\begin{array}{c}100 \\
90 \\
80 \\
70 \\
60\end{array}$ & $\begin{array}{r}0 \\
10 \\
20 \\
30 \\
40\end{array}$ & $\begin{array}{l}50 \\
50 \\
50 \\
50 \\
50\end{array}$ & 950 \\
\hline \multirow{3}{*}{$\begin{array}{l}\text { Compactadas } \\
\text { Manualmente } \\
\text { por apisona- } \\
\text { miento } \\
\text { (Manual } \\
\text { compactation } \\
\text { through } \\
\text { ramming) }\end{array}$} & $\begin{array}{l}\text { (A) } \\
\text { (E) } \\
\text { (D) }\end{array}$ & $\begin{array}{r}100 \\
60 \\
70\end{array}$ & $\begin{array}{r}0 \\
40 \\
30\end{array}$ & $\begin{array}{l}25 \\
25 \\
25\end{array}$ & 450 \\
\hline & (C) & 80 & 20 & 30 & 550 \\
\hline & (B) & 90 & 10 & 35 & 650 \\
\hline
\end{tabular}

que se determinó la tensión media de fractura a la compresión para cada dosificación y para cada proceso de fabricación. Antes de ensayar a la compresión las probetas cilíndricas fabricadas por compactación manual se refrentaron sus caras para dejar paralelas sus bases. También se ensayaron a la compresión las probetas que resultaron ilesas del test de fatiga con el fin de determinar su pérdida media de resistencia. En la determinación de la tensión media de fractura a la compresión se computó como tensión nula las ya fracturadas por efecto del choque térmico.

\section{RESULTADOS Y DISCUSIÓN}

En la Fig. 1 podemos apreciar el resultado de aplicar la temperatura inicial de trabajo de $1.000^{\circ} \mathrm{C}$ a muestras de pasta pura de cemento y a muestras del cemento refractario cemento-talco, de dosificación $65 \%$ cemento - $35 \%$ talco, fabricadas por el método de compactación a $350 \mathrm{~kg} / \mathrm{cm}^{2}$. Todas las probetas de pasta pura de cemento presentaron el deterioro que se observa en la Fig. 1, es decir, una gran fisuración, no fueron capaces de resistir la temperatura de trabajo y por lo tanto no se sometieron al test del choque térmico ya que su pérdida de resistencia fue del $100 \%$. Mientras que las probetas de cemento-talco sólo un $6 \%$ de ellas presentaron una leve fisuración, el resto $94 \%$ resistió perfectamente este tratamiento térmico. Lo anterior es una prueba de la capacidad de la mezcla para resistir elevadas temperaturas. fracture stress under compression was determined for every dosification and every manufacturing process. Prior to compression testing the manually-compacted cylindrical specimens, their end faces were refaced in order to leave them parallel. In addition, the specimens that withstood the fatigue test were also compression tested to the end of ascertaining mean loss is strength. On the other hand, in the mentioned determination of mean fracture stress under compression, the specimens already fractured were computed as corresponding to a zero stress.

\section{RESULTS AND DISCUSSION}

Fig. 1 is showing the result of applying the initial working temperature of $1.000^{\circ} \mathrm{C}$ to the samples of neat-cement paste and to the samples of refractory cement containing $65 \%$ cement and $35 \%$ talc, all these samples having been produced through compactation to $350 \mathrm{~kg} / \mathrm{cm}^{2}$. All the neat-cement paste specimens exhibited the damage noticeable in Fig. 1, i.e. and extense cracking, and thus they were unable to withstand the working temperature; hence they were not subjected to the thermal shock test inasmuch as their strength loss amounted to $100 \%$. On the other hand, among the cement-talc specimens, only a $6 \%$ thereof exhibited a slight cracking while the remaining $94 \%$ withstood this thermal treatment perfectly. The foregoing is proving the capacity of the mixture to withstand high temperatures. 


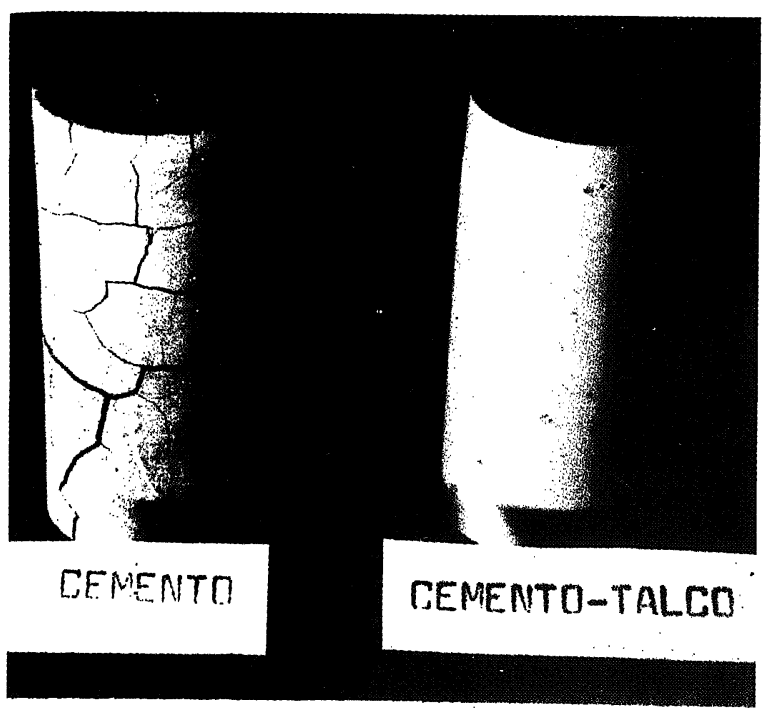

Fig. 1.-Probetas de pasta pura de cemento y de cementotalco después del tratamiento a $1.000^{\circ} \mathrm{C}$.

Fig. 1.-Specimens Made of Neat-Cement Paste and of Cement-Talc, After Being Subjected to the Thermal Treatment at $1.000^{\circ} \mathrm{C}$.

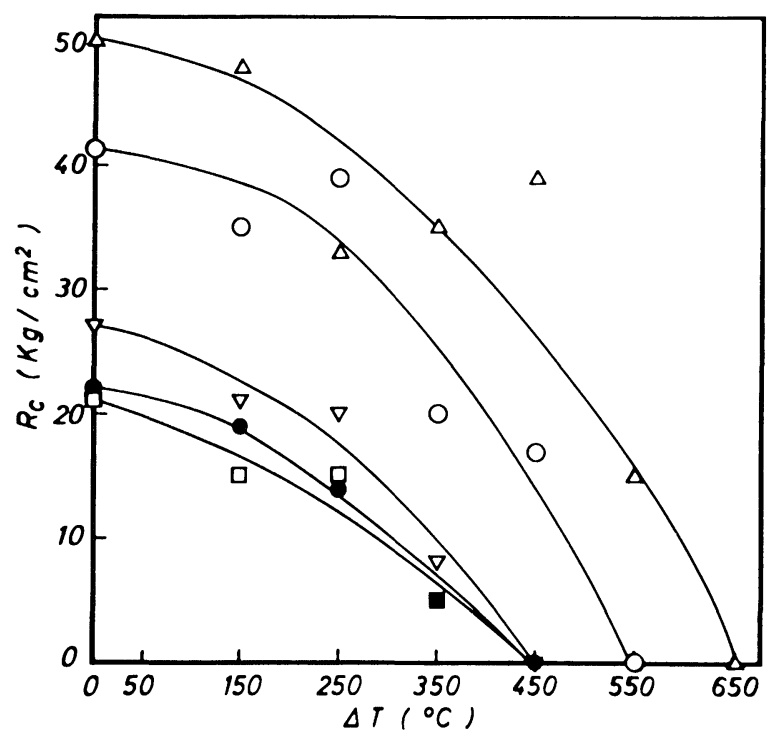

Fig. 3.-Resistencia media a la compresión. Probetas compactadas manualmente con un pisón. Dosificaciones de chamota: $A(\Delta)=0 \%$; $B(\Delta)=10 \% ; C(O)=20 \%$; $D(\bullet)=30 \% ; E(\square)=40 \%$.

Fig. 3.-Mean Compressive Strength. Specimens Manually Compacted Through Ramming. Chamotte Dosifications: $A(\Delta)=0 \% ; B(\Delta)=10 \% ; C(O)=20 \% ; D(\bullet)=30 \%$; $E(\square)=40 \%$.

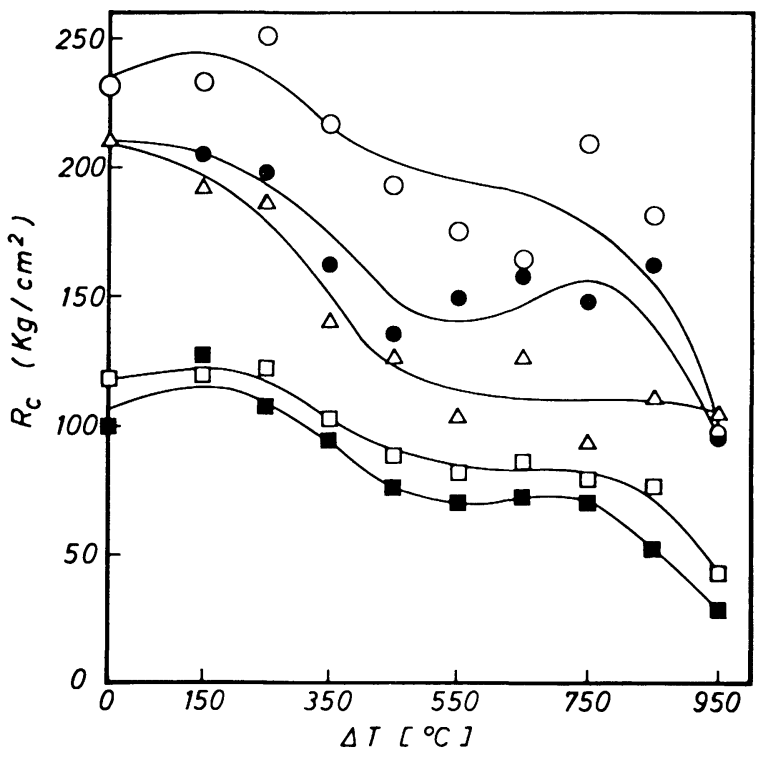

Fig. 2.-Resistencia media a la compresión. Probetas compactadas a $350 \mathrm{~kg} / \mathrm{cm}^{2}$. Dosificaciones de chamota: $A(\Delta)=0 \% ; B(O)=10 \% ; C(O)=20 \% ; D(\square)=30 \%$; $E(\square)=40 \%$.

Fig. 2.-Mean Compressive Strength Specimens Compacted to $350 \mathrm{~kg} / \mathrm{cm}^{2}$. Chamotte Dosifications: $A(\Delta)=0 \% ; B(O)=10 \% ; C(\bullet)=20 \% ; D(\square)=30 \%$; $E(\boldsymbol{\nabla})=\mathbf{4 0} \%$.

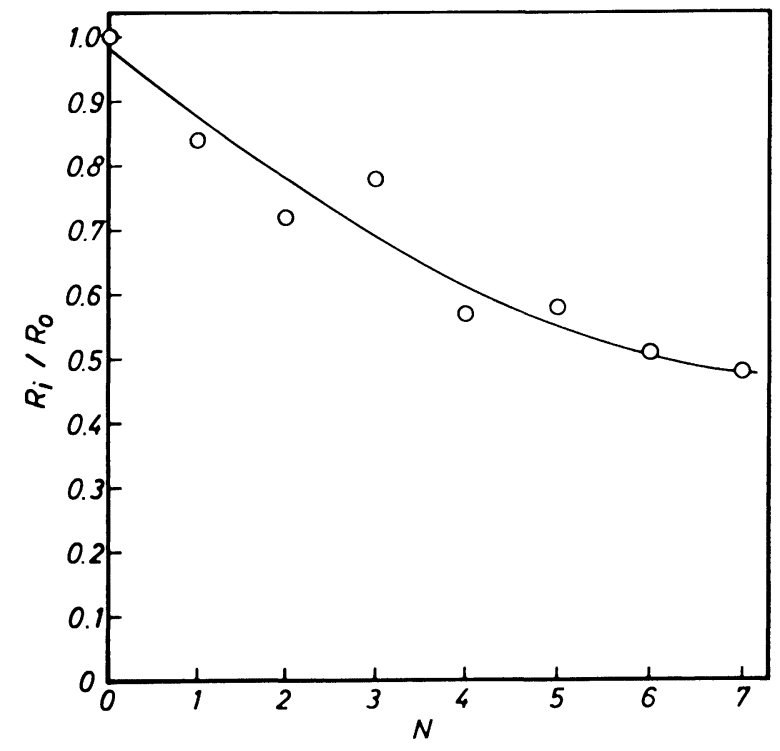

Fig. 4.-Fatiga térmica. Porcentaje de reducción de resistencia media a la compresión. Choques térmicos sucesivos con $\Delta T=500^{\circ} \mathrm{C}$. $R_{N}$ resistencia a la compresión después de $N$ choques térmicos; $R_{0}$ : resistencia a la compresión a temperatura de sala $T_{0}$, sin choque térmico.

Fig. 4. - Thermal Fatigue. Reduction \% in Mean Compressive Strength. Succesive Thermal Shocks with $\Delta T=500^{\circ} \mathrm{C} . R_{N}=$ Compressive Strength after $N$ Thermal Shocks. $R_{o}=$ Compressive Strength at Room Temperature $T_{0}$ without Thermal Shock. 
Las probetas de las cinco dosificaciones preparadas mediante los dos procesos de fabricación resistieron el tratamiento térmico a $1.000^{\circ} \mathrm{C}$ y se les aplicó entonces el test del choque térmico. Aquellas probetas fabricadas por compactación manual presentaron una pobre resistencia al desgaste, con una simple fricción manual se desprendía polvillo de ellas. Las variaciones de las resistencias medias a la compresión en función de la diferencia de temperatura aplicada en el choque térmico se muestran en las Figs. 2 y 3.

En la Fig. 2 podemos apreciar que para probetas fabricadas por compactación a $250 \mathrm{~kg} / \mathrm{cm}^{2}$ la dosificación óptima, frente al choque térmico, es aquella que contempla un $10 \%$ de chamota y $90 \%$ de cemento-talco. En la respectiva curva de resistencia media a la compresión, para un $10 \%$ de chamota, se observa primero un incremento de dicha resistencia hasta alcanzar $\Delta \mathrm{T}=250^{\circ} \mathrm{C}$ para luego descender paulatinamente hasta alcanzar $\Delta \mathrm{T}=650^{\circ} \mathrm{C}$ y finalmente caer bruscamente hasta alcanzar $\Delta T=950^{\circ} \mathrm{C}$ producto de la severidad del test aplicado. Se tiene un $10 \%$ de incremento en la resistencia media a la compresión al pasar de una dosificación de $0 \%$ a $10 \%$ de chamota. Las dosificaciones de $30 \%$ y $40 \%$ de chamota son insatisfactorias puesto que las respectivas curvas de resistencia media quedan por debajo de la curva correspondiente a $0 \%$ de chamota. Notemos además que todas las dosificaciones completan el test del choque térmico hasta alcanzar $\Delta \mathrm{T}=950^{\circ} \mathrm{C}$. La dosificación cemento-talco puro, i.e., $0 \%$ de chamota presenta una pérdida media de resistencia a la compresión de $50 \%$ entre $\Delta \mathrm{T}=0^{\circ} \mathrm{C}$ y $\Delta \mathrm{T}=950^{\circ} \mathrm{C}$, en tanto que con un $10 \%$ de chamota la pérdida media de resistencia es del $58 \%$. Para valores de $\Delta T$ próximos a $1.000^{\circ} \mathrm{C}$ las probetas que sobrevivieron al choque térmico no pasaron del $10 \%$.

En la Fig. 3 para probetas fabricadas por compactación manual o apisonadas se aprecia en primer término la diferencia en las curvas de resistencia media respecto del proceso de fabricación por compresión a $350 \mathrm{~kg} / \mathrm{cm}^{2}$. Al igual que allí la dosificación óptima corresponde a una mezcla con un $10 \%$ de chamota y se mantiene también la posición relativa de las curvas respecto de los porcentajes de chamota agregados. Para valores de $\Delta T$ por sobre los $600^{\circ} \mathrm{C}$ las probetas no resistieron el choque térmico fracturándose espontáneamente al tomar contacto con agua a $20^{\circ} \mathrm{C}$. La dosificación cemento-talco puro, i.e., $0 \%$ de chamota presenta una pérdida media de resistencia del $100 \%$ a un $\Delta \mathrm{T}=450^{\circ} \mathrm{C}$, mientras que con un $10 \%$ de chamota se alcanza igual pérdida media de resistencia a un $\Delta T=650^{\circ} \mathrm{C}$. Hay un incremento del $85 \%$ en la resistencia media a la compresión al pasar de una dosificación de $0 \%$ a $10 \%$ de chamota. Si comparamos ambos
The specimens of the five dosifications prepared in keeping with the two manufacturing processes withstood the thermal treatment at $1.000^{\circ} \mathrm{C}$, and then they were subjected to the thermal shock test. Those specimens that had been manually compacted exhibited poor resistance to wear inasmuch as simple manual rubbing caused the removal of fine powder therefrom. The variations in mean compressive strength as a function of temperature difference applied in the thermal shock, are shown in Figs. 2 and 3.

Fig. 2 allows to observe that regarding the specimens compacted to $350 \mathrm{~kg} / \mathrm{cm}^{2}$ the optimum dosification withstanding thermal shock is that comprising $10 \%$ chamotte and $90 \%$ cement-talc. In the correponding curve of mean compressive strength for $10 \%$ chamotte there is first an increase in that stregth till reaching $\Delta T=250^{\circ} \mathrm{C}$, thereafter there is a gradual decrease till attaining $\Delta T=650^{\circ} \mathrm{C}$, and finally there is a sudden fall to $\Delta T=950^{\circ} \mathrm{C}$ as a result of the rigorousness of the test applied. A $10 \%$ increase in mean compressive strength is obtained when chamotte dosification is increased from $0 \%$ to $10 \%$. Chamotte dosifications amounting to $30 \%$ and $40 \%$ are unsatisfactory because the respective curves of mean strenth remain below the curve corresponding to $0 \%$ chamotte. In addition it should be noted that all the dosifications are completing the thermal shock test until reaching $\Delta T=950^{\circ} \mathrm{C}$. The cement-talc dosification without chamotte is exhibiting a $50 \%$ mean loss in compressive strength between $\Delta T=0^{\circ} \mathrm{C}$ and $\Delta T=950^{\circ} \mathrm{C}$ while the inclusion of $10 \%$ chamotte causes a mean loss in strength amounting to $58 \%$. For $\Delta T$ values in the vecinity of $1.000^{\circ} \mathrm{C}$ the specimens that withstood thermal shock did not exceed $10 \%$.

Fig. 3 for the manually rammed specimens allows to observe first of all the difference in mean strength curves compared to those for compactation to $350 \mathrm{~kg} / \mathrm{cm}^{2}$. As in that instance of manufacture, the optimum dosification corresponds to a mixture containing $10 \%$ chamotte, and the relative position of the curves concerning the different percentages of chamotte added, is maintained. For $\Delta T$ values above $600^{\circ} \mathrm{C}$ the specimens do not withstand thermal shock and thus they fracture spontaneously on contacting water at $20^{\circ} \mathrm{C}$. The cement-talc dosification without chamotte is exhibiting a $100 \%$ mean loss in strength at a $\Delta T=450^{\circ} \mathrm{C}$ while the dosification including $10 \%$ chamotte is attaining a like mean loss in strength at a $\Delta T=650^{\circ} \mathrm{C}$. $A$ $85 \%$ increase in mean compressive strength is obtained when chamotte dosification is increased from $0 \%$ to $10 \%$. When comparing both manufacturing processes in the case of $\Delta T=0^{\circ} \mathrm{C}$, i.e. at room temperature $T_{o}$, it can be seen that 
procesos de fabricación para $\Delta T=0^{\circ} \mathrm{C}$, i.e., $a T_{0}$ tenemos para la dosificación cemento-talco puro una caída de resistencia media del $87 \%$ y para la dosificación óptima, con un $10 \%$ de chamota, una caída de resistencia media del $78 \%$, al pasar de probetas compactadas por compresión a 350 $\mathrm{kg} / \mathrm{cm}^{2}$ a probetas compactadas manualmente.

En la Fig. 4 tenemos el resultado del test de fatiga al aplicar choques térmicos sucesivos con $\Delta \mathrm{T}=500^{\circ} \mathrm{C}$ a probetas fabricadas por compactación a $350 \mathrm{~kg} / \mathrm{cm}^{2}$ con la dosificación óptima obtenida, con el test del choque térmico, ilustrado en las Figs. 2 y 3, es decir, $90 \%$ cemento-talco y $10 \%$ chamota como agregado. Al final del séptimo ciclo se observa una disminución del $52 \%$ en la resistencia media de fractura a la compresión. Además se aprecia un descenso suave y uniforme de dicha resistencia que tiende a estabilizarse después del sexto ciclo. Hay que considerar que se trata de un test de fatiga bastante severo dado el tipo de material ensayado. Notar, por ejemplo, que ya en el tercer ciclo la relación de resistencias ha caído aproximadamente en un $30 \%$. En micrografías obtenidas con S.E.M. (aquí no se muestran) de probetas compactadas por compresión a 350 $\mathrm{kg} / \mathrm{cm}^{2}$ y que se les ha sometido al test de fatiga térmica, se aprecia la aparición de cristales no detectados en probetas no sometidas a dicho test, resultado que podría deberse a la formación de una nueva fase.

\section{CONCLUSIONES}

Todas las dosificaciones de cemento-talcochamota resistieron la temperatura de trabajo de $1.000^{\circ} \mathrm{C}$ con excepción de la pasta pura de cemento compactada que al fin de este tratamiento térmico previo presentó gran fisuración. Con el choque térmico a que se sometió a los dos grupos de probetas, unas compactadas a compresión a $350 \mathrm{~kg} / \mathrm{cm}^{2}$ y otras apisonadas manualmente, se obtuvo como dosificación óptima para el mortero refractario $90 \%$ cemento-talco y $10 \%$ chamota, para ambos procesos de fabricación. El primero de ellos resultó más eficiente que el segundo por cuanto, en la dosificación óptima, la resistencia media a la compresión se incrementa en un $10 \%$ respecto de la mezcla cemento-talco puro, además responde satisfactoriamente en todo el rango de temperaturas estudiado y su caída media de resistencia es del $58 \%$ a un $\Delta \mathrm{T}=950^{\circ} \mathrm{C}$ frente a una caída del $100 \%$ a un $\Delta T=650^{\circ} \mathrm{C}$ para el proceso de apisonado manual.

El test de fatiga térmica muestra un decrecimiento suave en la relación de resistencia después de siete choques térmicos sucesivos a un $\Delta \mathrm{T}=500^{\circ} \mathrm{C}$, con una caída media en la the pure cement-talc dosification (devoid of chamotte) is exhibiting a $87 \%$ loss in mean strength, and that the optimum dosification including $10 \%$ chamotte is exhibiting a $78 \%$ loss in mean strength, when shifting from the specimens compacted to $350 \mathrm{~kg} / \mathrm{cm}^{2}$ to those manually compacted.

Fig. 4 shows fatigue test results when applying succesive thermal shocks with $\Delta T=500^{\circ} \mathrm{C}$ to the specimens compacted to $350 \mathrm{~kg} / \mathrm{cm}^{2}$ and exhibiting the optimum dosification ascertained through the thermal shock illustrated in Figs. 2 and 3, that is, the dosification comprising $90 \%$ cement-talc and $10 \%$ chamotte aggregate. At the end of the seventh cycle a $52 \%$ reduction is noticed in mean strength of fracture under compression. In addition a smooth and uniform decrease in said strength ca be observed, and the same tends to stabilize itself after the sixth cycle. It should be borne in mind that the fatigue test applied is quite severe, taking into account the material tested. For instance it can be seen that already in the third cycle the strength relation has experienced a close to $30 \%$ reduction. S.E.M. micrographs (not shown here) of the specimens compacted to $350 \mathrm{~kg} / \mathrm{cm}^{2}$ and subjected to the thermal fatigue test, showed the appearance of crystals that were not detected in the specimens not subjected to said test, and this finding might be due to the formation of some new phase.

\section{CONCLUSIONS}

All of the cement-talc-chamotte dosifications withstood the working temperature of $1.000^{\circ} \mathrm{C}$, excepting the compacted neat-cement paste which, at the end of this prior thermal treatment, exhibited extense cracking. The thermal shock applied to the two gropups of specimens - namely, the one compacted to $350 \mathrm{~kg} / \mathrm{cm}^{2}$ and the other manually rammed-supplied for the refractory mortar the optimum dosification comprising $90 \%$ cement-talc and $10 \%$ chamotte in the cases of both manufacturing processes. The first process proved to be more efficient than the second one because its mentioned optimum dosification is exhibiting a mean compressive strength increased by a $10 \%$ in comparison with that of the cement-talc dosification; besides, its mentioned optimum dosification is also exhibiting a satisfactory response in the whole thermal range studied, and the corresponding mean strength decrease amounts to $58 \%$ at a $\Delta T=950^{\circ} \mathrm{C}$ while mean strength decrease in the case of manual ramming amounts to $100 \%$ at a $\Delta T=650^{\circ} \mathrm{C}$.

The thermal fatigue test is showing a smooth decrease in strength relation after seven successive thermal shocks at a $\Delta T=500^{\circ} \mathrm{C}$; with a mean loss in compressive strength amounting to 
resistencia a la compresión de un $52 \%$, se aprecia en esta etapa la formación probable de una nueva fase, la que se observó con S.E.M.

La chamota como material inerte de baja conductividad térmica incrementa la resistencia al choque térmico en la mezcla cemento-talco. Sin embargo, a partir de cierto límite del porcentaje de chamota no continúa tal incremento, todo lo contrario, se reviste, puesto que ésta rompe la liga cemento-talco.

\section{AGRADECIMIENTOS}

Los autores expresan sus agradecimentos al Departamento Técnico de Investigación de la Universidad de Chile por los proyectos |-1544-8322, |-1544-842F, al Fondo Nacional de Desarrollo Científico y Tecnológico (FONDECYT) por los proyectos N. ${ }^{9} 516 / 88$ y N. ${ }^{\circledR} 1195 / 91$, al Programa de Dedicación Exclusiva (1989) de la Universidad de Chile, al profesor M. Ossa, jefe de la Sección Aglomerantes del IDIEM, por las facilidades con el equipo, al Sr. J. Saavedra, jefe de la Sección química de Materiales del IDIEM, por el uso de los hornos, al profesor E. Gómez, jefe de la Sección Investigación y Ensayos de Estructuras del IDIEM, por el uso del equipo de fractura, al Sr. H. Linacre por su ayuda con los ensayos.
$52 \%$, the likely formation of some new phase is observed with S.E.M. at this stage.

Chamotte is an inert material with low thermal conductivity and thus it increases thermal shock resistance of the cement-talc mixture. However, when exceeding a certain limit of chamotte percentage, such resistance increase does not continue any more but, quite on the contrary, reverts itself because then the chamotte starts breaking the cement-talc bond.

\section{ACKNOWLEDGEMENTS}

The authors would like to thank the Technical Department of Investigations of the University of Chile for Projects 1-1544-8322 and I-1544-842F, the Fondo Nacional de Desarrollo Científico $y$ Tecnológico (FONDECYT) for Grant N. ${ }^{\circ} 516 / 88$, y N. ${ }^{21195 / 91}$, the Exclusive Dedication Programme (1989) of the University of Chile, Professor M. Ossa, Head of the Agglomerants Department of the IDIEM Institute, for equipment facilities, Mr. $J$. Saavedra, Head of the Materials Chemistry Department of the IDIEM, for the use of the ovens, Professor E. Gómez, Head of the IDIEM Department of Investigation and Testing of Structures, for the use of fracture testing equipment, Mr. H. Linacre for his collaboration in the carrying out of the tests, and Mr. R. Toledo For his help with the manuscript.

\section{REFERENCIAS REFERENCES}

(1) A. F. LIVOVICH: Ceram. Bull, 40, 559 (1961).

(2) P. KITTL y M. RODRígUeZ: Res Mech. Lett., 1, 267 (1981).

(3) P. KITTL, M. ROdRígueZ, C. URRUTIA, H. ALARCÓN y G. DÍAZ: Latin. Am. J. Mettal. Mater., 4, 159 (1984).

(4) H. MITUSCH: Report of the German Ceramics Society, 9, 454 (1962). 